Sonila Danaj* and Ines Wagner*

\title{
Beware of the "poverty migrant": media discourses on EU labour migration and the welfare state in Germany and the UK
}

\author{
https://doi.org/10.1515/zsr-2021-0001
}

\begin{abstract}
This article examines the role of the media in the EU freedom of movement debate through the lens of high-circulation German and UK newspapers during the first half of 2014. It explores how the media problematised migration from Eastern European member states and its influence on national host country labour markets and welfare systems. It also analyses how different media outlets positioned themselves in relation to relevant policies or policy proposals. The findings show that most articles in our sample present low-skill, low-wage working European Union (EU) migrant class referred to as "poverty migrants" as a problem to be addressed at the policy level in contrast with the economically self-sufficient migrant with marketable skills. The article contributes to discussions on work, welfare, and mobility in the EU by cross-fertilising the literature on migration policy, freedom of movement, social rights, and the media.
\end{abstract}

Keywords: EU migrants, poverty migrant, print media, Germany, UK

\section{Introduction}

Any European Union (EU) citizen has the same right to work in another EU country as nationals of that country. By law, every EU citizen also has equal access to social security rights as long as they are in employment. Even in marginal employment, the EU citizen is entitled to in-work benefits. However, within the pan-European labour market, the economic disparities amongst member states place pressure on wages in certain sectors or jobs. This EU labour migration regime leads to publicly expressed fears of an influx of lower wage workers taking away jobs from native workers and of intra-EU migrants who do not contribute sufficiently to the host society. The media are also participating and contributing to public discourses on how migration is influencing receiving

\footnotetext{
*Contact: Sonila Danaj, University of Jyväskylä/European Centre for Social Welfare Policy and Research, Berggasse 17, 1090 Wien, Austria, Email: danaj@euro.centre.org Ines Wagner, Institute for Social Research, Oslo, Lyder Sagens gate 25, 0358 Oslo, Norway, Email: ines.wagner@socialresearch.no
} 
societies. This article builds on literature discussing the relationship between work, welfare, and mobility in the EU (Lafleur/Stanek 2017; Bruzelius et al. 2016) and its portrayal in the media. The contradictions of EU freedom of movement, economic disparities among member states and national welfare states triggering discussion of "social dumping" and the like have been the focus of several studies (e.g., Arnholtz/Lillie 2020; Jurado/Brochmann 2013). However, this article looks beyond the material practice of labour market exclusions and examines specifically the role of the media in the EU freedom of movement debate. We ask how the media problematises intra-EU migrants in relation to the welfare state and the labour market. To do this, we focus on six mainstream print media in Germany and the UK, two western member states that receive among the highest number of workers from other member states.

The article is based on a comparative analysis of major German (Die Zeit, Die Welt and Frankfurter Rundschau) and British (Daily Mail, The Guardian, and The Times) newspapers covering the six-month period from the lifting of the ban for Romania and Bulgaria at the beginning of 2014 until right before the European Parliamentary elections.

In our analytical approach, we draw on competing frames of representation (Gamson/Modigliani 1989), which means that for each media representation, or framing, of an issue - in our case, the impact of EU migration on the host societies of Germany and the UK - we identify alternate representations or their counterframe within the existing media discourses, which is useful in recognizing and interpreting media practices in creating contrasting assumptions and beliefs in their efforts to win support and/or opposition for specific courses of action (Gamson 1992). We find that despite the existence of competing frames of representation, in which EU migrants are portrayed as both contributing and putting a strain or abusing the national labour markets and welfare systems in the two countries, most articles in our sample present low-skill, low-wage working EU migrant class as a problem. We refer to this type of migrant as "poverty migrant" and describe how media discussions in both countries construct an underclass of workers as a separate category in contrast with the economically self-sufficient migrant with marketable skills. By "underclass", we refer to a segment in the population that occupies the lowest possible position in a class hierarchy, thus below the core body of the working class (Massey/Denton 1993). In both countries, the "poverty migrant" has become part of an underclass deplored for their dependence on welfare and feared for their ability to abuse the welfare system of the host state. In Britain, they are also targeted for undermining labour standards through practices of unfair competition for local jobs. The article also discusses these media's perspective on the political reforms that 
reduce social benefits for EU migrants, which is relevant to discussions on the overall legitimacy of freedom of movement in the EU. According to media discourses in Germany, the restriction of EU liberties for this segment could reestablish the legitimacy for EU freedom of movement. By contrast, the UK findings show that freedom of movement is connected to a fundamental critique of EU integration. While restrictions on EU liberties were proposed in the UK as well, they did not alter the critique on freedom of movement itself, as in the German case. These findings point to the importance of taking the lens of mainstream media discourse into account when examining how discursive media constructs such as "poverty migrants" are used to discuss related policy reform in the UK and Germany.

The article proceeds as follows. First, it discusses the literature on labour migration, the welfare state and mediated political discourse. After explaining the methodological approach, we provide a quick overview of relevant national and EU policy in relation to labour migration and the welfare state in both countries. In the empirical part, we present findings from a selection of articles published in daily mainstream newspapers in Germany and the UK in order to further our understanding of the development of the media discourses on labour migration and policy related to intra-EU labour migration. The analysis interrogates how (1) freedom of movement is problematised in the media; (2) EU migrants are described in the media; (3) national policy responses are discussed in the media; and 4) the national media discussions are linked to critiques on the freedom of movement in the EU. Finally, we discuss the findings and conclude.

\section{Labour migration, the welfare state and mediated political discourse}

The EU has established a common labour market in which workers can move individually to another country to take up work or can be sent by a company for a service contract. Studies examining intra-EU migration have often focused on the impact of mobile EU citizens on the receiving countries' labour markets and welfare states (e.g. Black et al. 2010; Bruzelius et al. 2016; Lafleur/Stanek 2017; Luthra et al. 2016). They have identified institutional differences across countries and sectors and discussed how intra-EU labour migration places pressure on national labour markets and welfare institutions (Arnholtz/Hansen 2013; Barrett et al. 2012; Jurado/Brochmann 2013). In particular, circular and temporary migration movements, such as posted work or temporary agency work, have been discussed as driving down wages and challenging the benefits distri- 
bution system of the host country population because of the influx of cheaper labour (Cremers 2011; Lillie 2010: 693; Wagner 2018). Research has focused on three main aspects: the tensions and contradictions of migration and welfare policymaking at the national and EU level (e.g., Geddes/Hadj-Abdou 2016; Jurado/Brochmann 2013; Roos 2016), the impact of migration on the host state (e.g., Lafleur/Stanek 2017) and the impact of these policies on migrants themselves (Bruzelius et al. 2016; Alberti/Danaj 2017; Ehata/Seeleib-Kaiser 2017; Heindlmaier/Blauberger 2017; Shutes 2016).

While these studies in the industrial relations and welfare literatures have focused on the consequences for the welfare state and labour market institutions when EU migrants appear on the scene, triggering discussion of "social dumping" and the like, there is a lack in understanding of the concurrent process which produces norms and opinions on intra-EU migrants in relation to the welfare state and the labour market. In particular, they have not explained how the media have portrayed incoming migration trends and related policy areas.

Differently from the industrial relations and welfare literatures on migration, the framing of immigrants as a threat to national security, societal order, and social resources has been more attentively discussed in the media and immigration literature (Boomgaarden/Vliegenthart 2009; Caviedes 2015; Freeman et al. 2013; Mawby/Gisby 2009; Schemer 2012; Schlueter/Davidov 2011). In particular, the recurring negative discourses that consider immigrants a threat to welfare state benefits and portray benefit recipients of migrant background as welfare scroungers and frauds who have turned into an economic burden for the hard-working tax-paying majority (Golding 2002; Larsen/Dejgaard 2013), referred to in the literature as welfare chauvinism (Balch/Balabanova 2016; Bommes/Geddes 2000), have received considerable attention. Social problems such as unemployment and the insufficiencies of welfare regimes are discursively transformed into a public crisis in the media, which target immigrants as the ultimate societal culprits and demand preventative and controlling policy changes (Anderson 2013). Rather than promoting a common market with a shared European identity and similar values, the debate leads to backlash against free movement. These positions are encouraged by actual as well as perceived negative effects that influence policy in various ways (Roos 2016). Thus, freedom of movement and European integration can become politicised through legal uncertainty (Blauberger/Schmidt 2014), policy misfit (Roos 2016) as well as the media (Balch/Balabanova 2016).

In this article, the focus is placed on the politicised media construct of the "poverty migrant" and how changes in policy occurred in these two countries' media contexts (De Wilde/Zürn 2012). Politicisation is here understood as an 
"increase in polarization of opinions, interests or values" in the public discourse with the aim of changing a given policy (De Wilde 2011: 566). Studies on agenda-setting suggest the media are able to make some issues more salient than others and shift the attention of the public to certain attributes of those issues compared to others, hence influencing how the issues are understood by the public (see McCombs 2004; Wolfe et al. 2013). Scholars in the media framing tradition argue that the way media frame issues can affect the way the public evaluates politics, politicians and policies, thus influencing not only what they think about but also how they think about it, which has implications for their subsequent behaviour (Gamson/Modigliani 1989; McCombs 2004; Wolfe et al. 2013). Furthermore, policy-oriented research within the media literature pinpoints the role that media play in the process of defining an issue as a public problem that needs to be addressed through policy change (Baumgartner/Jones 2002). These interpretations suggest that the media are interested in policymaking only when it is problematised, although they often not only report a policy crisis but can also construct it (Franklin 2002). Especially in relation to portrayals of welfare recipients, recent studies show that the classification of certain segments of society as "deserving" or "undeserving" is not a matter of "deepseated beliefs and ideological convictions" but subject to "strategic manipulation in the new reality of ...mediatized politics and professionalized political communication" (Esmark/Schoop 2017: 2).

\section{Methodology}

The two country cases, Germany and the UK, provide a valuable "laboratory" for examining the development of mediated public debates on immigration due to their distinct national political circumstances (Esping-Andersen 1990) and their two different stances on the EU. The selected period is also important because of two key events that disrupted national discourses encouraging political, media and public debates on labour migration, namely the lifting of the ban for citizens of Bulgaria and Romania, the two newest member states, to travel for work purposes to the rest of the EU and the election of the representatives for the European Parliament. The underlying context was also the anticipation of the British national elections in 2015. The lifting of the restrictions on Romanian and Bulgarian worker mobility in 2014 increased the political salience of the topic of intra-EU mobility as an issue of public concern in both Germany and the UK (Blauberger/Schmidt 2014; Balch/Balabanova 2016). Comparing Germany and the UK is thus relevant because both countries have a similar level of mi- 
grant residents from Eastern Europe (1.3 million in the UK and 1.2 million in Germany, according to Eurostat 2016) and both experienced an increase in media attention to migration from the new Eastern European member states.

To understand how the media problematises intra-EU migrants in relation to the welfare state and the labour market in the wake of the removal of restrictions to the EU labour market for Bulgarian and Romanian workers and the European Parliament elections, we analyse a selection of articles published in daily mainstream newspapers in the UK (Daily Mail [including its weekend issue The Mail on Sunday], The Guardian and The Times) and Germany (Die Zeit, Die Welt and Frankfurter Rundschau) for the first half of 2014. We focus on professional journalism and mass media as opposed to social media in order to study mass professional public opinion instead of private opinions in relation to our cases. The German media quotes have been translated by the author. Our sample included both broadsheets and tabloids, as well as print media that are perceived by readers to be situated at different points of the political spectrum: The Guardian (left), The Times (centre/centre-right), Daily Mail (right), (Smith 2017; Pew Research Center 2018), Frankfurter Rundschau (progressive), Die Welt (conservative) and Die Zeit (social liberal) (University of Chicago Online Resources n.d.). We use this varied range of media in an attempt to capture the nuances of migrant portrayal across the print media political spectrum in both countries. Newspaper articles were chosen for "their very ubiquity, coupled with intensity of usage, public attention and political influence" (Mautner 2008: 32). As media products, these articles reflect the constitutive context in which and about which they are articulated, and through them we can observe what is said about our topic of interest and how it is said (Billig 1991). The study of media discourses is important in understanding how public opinion is formed on a particular issue. Discourse as a mode of action and representation helps us to understand the positions and attitudes of those that have constructed such discourse and identify some of the influences to which public opinion is exposed (Fairclough 1992).

The initial article selection was based on a Lexis Nexis search with the following keywords:
a. freedom of movement + migration + labour
b. migration + welfare - asylum
c. migration + labour + EU + Germany/UK
d. migration + job $+\mathrm{EU}+$ Germany/UK. 
The screening of the articles led to the identification of two other terms, which we then used as search keywords to ensure no articles were excluded, especially in the case of social/benefits tourism:

e. poverty migration (Armutsmigration)

f. social tourism (Sozialtourismus and benefits tourism as a synonym used in Germany and the UK respectively)

This search produced many articles (265 in the UK and 223 in Germany), which were narrowed down through a cyclical process (Mautner 2008). More specifically, the articles were carefully screened by the authors, and the ones that only briefly mentioned or did not discuss the issue of labour migration and its implications to the welfare state were removed. We also removed interviews with politicians because although the choice of interviewees and the questions is shaped by editorial policy, they nevertheless represent the positions of the politicians interviewed rather than the journalists. Thus, this study was based on editorial and news articles whose central theme was that of labour migration and welfare, which led to a saturated sample of 90 articles in Germany and 104 in the UK. Certain quotes and statements from national or EU politicians and officials are used only in the context of media reactions to national policy responses.

The keywords for the search were used as sensitising concepts (Blumer 1954) - i.e. a starting point and guidance for us in directing our attention. As such, their fluidity allowed us to explore them and be open to new attributes that helped refine them with new, appropriate, context-specific ones (see Blumer 1954; Blaikie 2000), which allowed us to identify the category of "poverty migrant" as separate and distinguishable from both other (highly skilled) migrants as well as the local workforce. We analysed the data using critical discourse analysis focusing on problematization, i.e. the mediated political discourses that make the problems visible and intelligible (Foster 2010; Gamson 1992; Patterson 2008; Wodak/Meyer 2009). We identified competing frames of representation (Gamson/Modigliani 1989), which means that for each media representation or framing of an issue - in our case, the impact of EU migration on the host societies of Germany and the UK - we identified alternate representations or their counterframe within the existing media discourses (Gamson 1992). In this article, we specifically discuss the competing frames of representation on the problematisation of EU migration, the characteristics of the EU labour migrants, national policies and EU policies related to EU migration and their impact on Germany and the UK's labour market and welfare state. 
The data analysis for the article was inductive: the first layer of analysis was descriptive, as the authors read through the articles and described the segments on EU migration to Germany or the UK. The process yielded several codes, which the authors discussed and then re-grouped into family codes, from which the main themes that were used to structure the article were identified (see Table 1).

Table 1: Main themes and codes

\begin{tabular}{|c|c|c|}
\hline Themes & Family codes & Codes \\
\hline \multirow[t]{4}{*}{ Problematising EU migration } & Migrant numbers & rising numbers, falling numbers \\
\hline & Labour market & $\begin{array}{l}\text { cheap labour, wage dumping, unemploy- } \\
\text { ment, taking jobs, not taking jobs, creat- } \\
\text { ing jobs, poverty migra- } \\
\text { tion/Armutsmigration }\end{array}$ \\
\hline & National welfare & $\begin{array}{l}\text { strain, no strain, social/benefit tour- } \\
\text { ism/Sozialtourismus: abuse, no abuse, } \\
\text { social dumping }\end{array}$ \\
\hline & National politics & insufficient measures, political posturing \\
\hline \multirow{2}{*}{$\begin{array}{l}\text { Characteristics of EU mi- } \\
\text { grants }\end{array}$} & Highly skilled & needed, beneficial, less than low-skilled \\
\hline & Poverty Migrant & $\begin{array}{l}\text { low-skilled, unskilled, poor, cheap, } \\
\text { benefit scroungers, welfare criminals, } \\
\text { Roma (ethnic minority), tensions with } \\
\text { local workforce }\end{array}$ \\
\hline \multirow[t]{4}{*}{$\begin{array}{l}\text { Media reactions to national } \\
\text { policy responses }\end{array}$} & Immigration policy & $\begin{array}{l}\text { migration numbers management, access } \\
\text { to national labour market }\end{array}$ \\
\hline & Welfare policy & access, eligibility criteria, enforcement \\
\hline & Other policy & $\begin{array}{l}\text { employment policy reform, systemic } \\
\text { change, migration and welfare policy } \\
\text { intertwining }\end{array}$ \\
\hline & EU policy & $\begin{array}{l}\text { EU freedom of movement reform, welfare } \\
\text { access reform, the relationship with the } \\
\text { EU/EU institutions }\end{array}$ \\
\hline
\end{tabular}

Source: own illustration.

The analytical process for the article then followed. For example, we examined the theme "characteristics of EU migrants", saw how they were described in the 
media in both countries and built two family codes: "highly-skilled" and "poverty migrant". Each family code had its own codes, from which we saw that highly skilled migrants were considered acceptable and beneficial but were not considered the main group of received EU migrants. Poverty migrants, on the other hand, were described in terms of their labour skills (low-/unskilled), economic background (poor), labour market impact (cheap), welfare impact (benefit scroungers, welfare criminals), ethnic background (Bulgarian/Romanian/Roma) and relation to the local workforce (tensions with local workforce). During the analysis, we realised that there were two competing frames within each country's media discourses that could be distinguished among the different papers. For example, Daily Mail and The Guardian in the UK and Frankfurter Rundschau and Die Welt in Germany held mostly opposite views on the themes we identified. The analysis also revealed the differences between the two countries, particularly in the case of EU policy, which is discussed in the next sections of the article.

\section{Relevant national and EU policy in relation to labour migration and the welfare state}

Before we present the empirical findings as to how the selected media partakes in the discussion on labour mobility and related portrayals of migrant workers and proposed policies, this section will present the policy background against which the media discussion took place.

During the 2004 Eastern European enlargement, only Ireland, Sweden and the UK did not put any transitional periods to their labour market access, which, combined with their rather lower unemployment rate compared to most EU-15 countries, resulted in the UK becoming one of the main receiving countries for migrant workers from the new member states of Eastern Europe. Despite the temporary ban on their own labour market and a fluctuating unemployment rate, Germany remained one of the main target countries for Eastern European migrant workers (Galgóczi et al. 2013). The unanticipated numbers triggered political and public debates that concentrated on the impact large-scale Eastern European migration was having on the receiving societies, as well as on issues of access to the national labour markets and social welfare systems. By the time of the 2007 Eastern Enlargement, when Bulgaria and Romania were accepted to the EU, all member states agreed to a transitional period before opening their labour markets. By 2014-2015, when the ban to access was lifted, the number of 
EU citizens residing in the UK had reached 1.3 million and 1.2 million in Germany (Eurostat 2016), the political debate had intensified, and governments in both countries were discussing and taking various measures.

In Germany, national level policies were informed by the case of a job centre in Berlin that stopped paying social security benefits to an EU citizen after she and her daughter had been receiving unemployment benefits for a year. Child support had also been paid for two more children. This culminated in an ECJ ruling on when EU labour migrants can receive social benefits (Dano v Jobcenter Leipzig (2014) C-333/13). The ECJ ruled that denying social assistance to EU jobseekers from another EU country and to EU migrants who had no intention of finding work in Germany "does not contravene the principle of equal treatment" and that Germany also had a right to refuse benefits. Within the limited scope for policy change that EU primary and secondary law leave to member states, some further scrutiny was decided by the German Bundestag in late 2014. For example, child allowance would only be granted upon tax identification in order to avoid double payments. Moreover, the right to reside as a jobseeker was reduced to six months. Next to legislative changes, a new decree on registering a trade scrutinises applications for self-employed status more rigorously in order to avoid bogus self-employment (BMI/BMAS 2014: 95). Legislative loopholes allowing fraud were thus addressed in Germany. Arguably, restricting residency criteria for EU jobseekers from indeterminate to six months goes beyond the prevention of fraud. It restricts possible social assistance claims that are justified the longer the EU migrant resides in the host country. Accordingly, welfare state protectionism led to the possible restriction of EU freedom of movement for people with few private resources and who rely on state-sponsored social assistance.

The ECJ ruling that limited access to benefits for EU jobseekers was applauded by British politics. One Liberal Democrat MEP, Catherine Bearder, said that the ruling had "huge implications for the current EU debate in the UK. It confirms that jobseekers from elsewhere in the EU are not automatically entitled to claim benefits. I hope the myth of benefit tourism will now be put firmly to bed" (BBC 15 September 2015). Meanwhile, new national regulations that came into force in the UK during 2014 specified that EU migrant jobseekers could not receive out-of-work benefits, child tax credit or child benefit within the first three months after arrival (House of Commons 2015). Unemployment benefits and child benefits could be claimed by newly arrived immigrants only after three months of residence in the UK. In addition, EU migrants could only claim jobseeker's allowance for six months unless they had genuine prospects of finding work. 


\section{Problematising EU migration in German and British media}

The lifting of the ban for Romanian and Bulgarian workers to access the EU labour market at the beginning of 2014 triggered an elevated discussion on the overall EU freedom of movement, particularly from Eastern European member states, in both German and British media. One frequent debate was whether EU labour migration is a problem for the two host societies. The main aspects discussed included the scale of Eastern European migration and its geographical distribution, the characteristics of the incoming migrant population, their impact on the labour market and their impact on the welfare system of the receiving societies. In our analysis, we found two main competing frames (Gamson/Modigliani 1989): one holding a positive view on the overall impact of Eastern European migration and the other negative. In this section of the article, we will discuss the problematisation of Eastern European migration to Germany and the UK in terms of scale and impact on these countries' labour markets and welfare states, whilst the characteristics of the EU migrant population will be described in the next section.

\subsection{Frame 1: EU labour migration is a problem}

Four papers in our analysis, namely Daily Mail and The Times in the UK and Die Welt and Frankfurter Rundschau in Germany, present EU labour migration as a problem. The two German papers discuss labour migration mainly as threatening to the national welfare system, whereas the two British papers identify labour migrants as a negative influence on both the labour market and the welfare state.

The British media are preoccupied with the large unmanageable numbers of EU immigrants: "We are now full" reads a headline in the Daily Mail (26 April 2014). Articles published in these papers express the fear of the pressure immigrants put on the British labour market, public services and welfare state. EU migrants are portrayed as causing high levels of unemployment, especially among youth, and the compression of wages. In addition, Daily Mail repeatedly problematises the relationship between immigration and other aspects of public life, such as housing, school and medical services:

There are two separate elements to our immigration problem. The first is the huge number of immigrants who have come to the UK in recent decades from outside the EU... The sec- 
ond is our inability to limit migration from the poorer parts of Europe...The actual incoming numbers matter as they put a strain on housing, school places, employment and medical services (Mail on Sunday, 1 June 2014).

German media, on the other hand, differentiates between the impact of EU migration on the German labour market and their welfare state. So, they stress that the population is not afraid of the overall impact EU migrants will have on the national labour market: "The large majority of the population says that we need highly skilled immigrants. Fear of foreigners taking away jobs, such as was seen in the past, has decreased significantly" (Die Welt, 14 January 2014). Yet, they argue that intra-EU labour migrants will strain the local social welfare system:

The impact on the social welfare providers is mostly felt in the large cities of Berlin, Duisburg and Munich. Despite the debate on national integration programs, the local situation has not changed in the last 12 months (Frankfurter Rundschau, 11 November 2014).

The German media portray an image that is concerned with the strain intra-EU labour mobility is putting on local social welfare providers. The portrayed concern is that local welfare authorities are not adequately financially equipped to accommodate workers from abroad in need of welfare assistance.

In addition to the strain, the media in both countries are also concerned about welfare abuse. Terms like "Sozialtourismus" [social tourism] and "benefits tourism" are used in the German and British media, respectively, to label EU migrants' intentions of moving to Germany or the UK in order to take advantage of, if not abuse, the welfare system of the host country. In Germany, the term Sozialtourismus is used to refer to unwanted immigrants from Eastern Europe, presuming that they merely come in search of social benefits. In the British media, benefit tourism emerges as a term used by politicians as both an existing and imminent policy issue that needs to be addressed urgently. Phrases that are used frequently in relation to social tourism are, for instance, "crackdown", "clamp down", "tackle” or "curb benefit tourism".

The German newspaper Frankfurter Rundschau also discussed the statement by one politician in Germany named Krings, from the conservative Christian Democratic Union (CDU) party, that "social tourism is not financially viable even for a rich industrial country like Germany" (14 January 2014). This statement created a discourse that portrays immigrants from Eastern Europe as lazy, migrating to Germany only to receive benefits.

These media challenged opposing voices on the issue of welfare abuse, especially when they came from the EU. In one article of the Daily Mail, the paper responded to a statement made by an EU official that "benefit tourism is a myth" by telling the story of a Romanian worker, who in an interview had de- 
clared he intentionally moved to the UK to take advantage of their welfare system:

This week, a top Eurocrat told Britain "Benefit tourism is a myth". He should read what Rudi and his huge Romanian family say at their new home in Nottingham (15 February 2014).

The article uses Rudi's testimony of moving to the UK because of its generous benefit system to reject the claim of the European official. This presentation depicts Eurocrats to be out of touch with the goings-on in the national contexts, whilst also drawing the stereotypical image of Romanian workers moving to the UK with their large families to depend on the British benefit system.

In the German media, it was noted that there are contradictory reports from the European level regarding whether Eastern European migrants abuse the welfare system:

There are contradictory signs from the European Union with regards to social tourism. On the one hand, there are studies reporting that it creates no burden for the social system. On the other hand, the European Commissioner for Justice, Viviane Reding, said that there is a right for mobility, but no right to immigrate into the national social security system (Frankfurter Rundschau, 14 Januar 2014).

Whilst the UK outlet firmly contradicted the opinion by the EU bureaucrat, the German outlet presented a more nuanced picture, in which it is still unclear whether such a thing as social tourism exists - possibly leaving the reader doubtful.

\subsection{Frame 2: EU labour migration is not a problem}

Die Zeit and The Guardian reject the claim that EU labour migration poses a welfare problem in each country: "The big question is if there is an abuse of the social welfare system by Bulgarians and Romanians. The statistics don't say so" (Die Zeit, 14 October 2014). The Guardian also uses figures to refute the claim that EU migrants are using or abusing the British welfare system, arguing that it is instead a fiscal benefit:

EU migrants' participation in the labour market - at 83\% - was higher than Britons' participation, while $1.7 \%$ of EU migrants were on jobseeker's allowance, half as many as Britons. The study said: "EU immigration is a fiscal benefit. 'Benefit tourism', if it exists at all, is a tiny problem" (9 February 2014). 
An article in The Guardian goes as far as to denounce politicians for using fear of labour migration to serve their political agenda and avoid addressing the social policy issues in the country:

... we have been subjected to a drumbeat of hysteria, as the Tories vied with the nationalist UK Independence party to terrify the public about the coming onslaught and promise ever more meaningless or toxic crackdowns, egged on by a xenophobic media.... In reality, the politicians are posturing because they can't control EU migration, but need a scapegoat for falling living standards, shrinking public services and the housing shortage. ...the Tories and their friends in the media have reached for the tried and tested alternative of blaming foreigners [emphasis added] (The Guardian, 02 January 2014).

In the six media outlets analysed here, we see various representations of EU labour migration, ranging from firmly portraying it as a problem, to painting a more nuanced picture, to denouncing it altogether. Nevertheless, the analysis shows that the claim that EU labour migration is problematic outweighs the claim that it is not.

\section{Characteristics of EU migrants: highly skilled vs. poverty migrants}

EU migrants in both German and British media are described in two categories: highly skilled migrants and poverty migrants. These categories present immigration along two dimensions: one that is desirable, based on its implications of certain skill characteristics, and another that is less desirable in connection with low-skill or unskilled migrants. The advantages of the first are presented as clear, whilst the second's impact is presented as implicitly undesirable or at least questionable. Both frames are discussed in this section.

\subsection{Frame 1: The desired highly-skilled}

The highly skilled migrants are described as desired across the different media in both countries; however, our analysis found fewer mentions of this frame than that of the undesired low-/unskilled ones. German media describe the recently arrived qualified Romanian or Bulgarian immigrants as desirable for the German labour market, while questioning the definition of qualification:

Most of the immigrants from Bulgaria and Romania are qualified employees. We need them in Germany, says a representative from the ministry of migration. Also, academics 
state that most of the migrants are good, qualified employees. However, what does qualified mean in this context: a doctor or a cab driver? (Die Welt, 2 January 2014).

The highly-skilled are portrayed in the British media, mostly in The Guardian and The Times, as desirable in terms of fulfilling the demands of the British labour market:

British companies are recruiting thousands of Romanian workers to plug gaps in the highly skilled jobs market and fill posts spurned by Britons (The Times 01 January 2014).

However, in our analysis, there were few articles that connected EU migration with positive attributes and with higher skill, as opposed to a portrayal of EU migrants as low skill or unskilled, as will be described in the following.

\subsection{Frame 2: The undesired EU poverty migrants}

Although the media in both countries recognise the value of highly skilled migrants, they are less receptive of the low-/unskilled ones. In the British media, the main portrayal of EU migrants is as "poor", typically Eastern European and specifically Bulgarian or Romanian. Poverty as an attribute is used to describe the sending country but also the individual. The huge economic differences between sending countries and receiving ones are described as an important pull factor towards the receiving countries:

... the financial incentives for Eastern Europeans to come and work in Britain are undeniably huge, especially if they bring their families. Some can earn eight times their pay at home (The Times, 11 April 2014).

In the selected British media articles, the adjective "poor" has been used 36 times, 28 times as an attribute for immigrants from Eastern Europe or their countries, two times to refer to Britain as becoming poor because of immigration and five times to describe places where immigrants are located in the UK. In only one sentence was it used to describe policies.

Apart from being poor, migrants are also described as predominantly unskilled or low-skilled:

Some immigration is necessary, of course, to bring in skills and entrepreneurship. Our future lies in the creation of a dynamic, productive economy, not a low-skill, low-wage one. Thus, the benefits of accepting millions of unskilled migrants are far from clear (Daily Mail, 18 June 2014). 
Although less prominent in the German media, the differentiation among migrants based on their value in the labour market feeds into the "desirable" and the "less desirable" categorisations in both national contexts, with the lowerskilled migrants portrayed as a threat to the German and British welfare systems. In one German media outlet, the paper asked about migrants coming to Germany:

But are they the right ones? Throughout the population, there is increasing fear that poverty migration will draw funds from the social welfare system (Die Welt, 14 January 2014).

As such, Die Welt's response to the immigration of certain migration groups was based on an economic classification of useful versus useless workers to their potential utility for sustaining the economy.

Moreover, attributes such as "poor" and "low-skill" in both British and German media imply this category is difficult to employ and will inevitably become a burden on the welfare system. Despite their poverty and low-skill background, these workers are paradoxically described as well-informed on the welfare systems of both countries. While German media consider the low unemployment figures and the well-functioning social welfare system as strong pull factors, in the British media, the social welfare system is considered an incentive to migrate to the UK not because it is well-functioning but because it is easy to abuse. In this understanding, low-/unskilled migrants' intention to exploit the British welfare system is presented as obvious:

Yet Rudi readily admits that our generous benefits' culture does encourage Romanians to uproot to the UK, where they can claim state money for the children, they bring with them. "Your benefits system is crazy I would actually say it was sick," he says.... Of course, Romanians will settle in Britain if they get this kind of money (Daily Mail, 15 February 2014).

Even in the German media, there are numerous examples in which the migrant is labelled as a welfare criminal. While firms are sometimes mentioned as abusers of the system, the intra-EU freedom of movement as such is never mentioned as a source of the problem. The focus is on the individual migrant and his or her criminal capacities, meaning unlawful abuse of the welfare system. These depictions of lower-class EU migrants are then used in the process of mediated othering in terms of "them" versus "us," "their" access to "our" welfare state benefits, the need of "us" to act "if migrants exploit the system" and that the state must design mechanisms to punish "them" in case of abuse.

In the British case, low-/unskilled EU migrants are portrayed as simultaneously relying heavily on benefits and still managing to be employed because they agree to be underpaid, hence creating a "new servant class, equal to that of 
Downton Abbey times” (Daily Mail, 6 March 2014). This characterisation as an underclass is used by certain media to describe a scenario of competitiveness, incompatibility, and inevitable conflict between British working class and the recent immigrants: "Working class hit hardest" reads the headline in Daily Mail (06 March 2014).

Overall, the media that perpetuate the second frame in both country contexts present a construct of a "poverty migrant" who is poor, low-skill, unemployable, benefit-abusing and criminal. These media in both countries portray a scenario in which local and poor migrant workers compete for scarce resources (welfare in both countries but also employment in the UK), which lays at the basis for their problematisation of EU migrants' presence and the appeal for protectionist and therefore restrictive labour market and welfare measures in their national contexts. Even though this article does not claim there is a causal relationship between the media using the term poverty migrant and the following policy implementations, it emerged from our analysis that the portrayal of poverty migrants was often used in connection with media's discussions on policy proposals that limited the rights of mobile intra-EU citizens, the topic we discuss further below.

\section{Media reactions to national policy responses}

German and British media not only problematised EU migration and discussed the characteristics of EU migrants; they were actively discussing national policies on the political agenda of the time. The stress was placed on prevention in the first frame and on the necessity to differentiate among the types of EU migrants when designing and implementing new measures in the second.

\subsection{Frame 1: Prevent the negative impact of low-/unskilled workers}

The analysed media repeatedly suggested either restricting the inflow of migrant workers or limiting access to welfare state benefits of EU migrant citizens in each country.

In Britain, several articles of the Daily Mail and The Times used "cut numbers" and "put a cap to migration" to indicate that overall migration needs to be minimized by preventing further inflows. Prime Minister Cameron and his coali- 
tion government were criticised in several articles for not being able to keep the number of immigrants coming to the UK under 100,000 as promised.

Apart from limiting EU migrants' entry into each country, the media were also focusing on the political debate about controlling immigrants already in the country through a system of monitoring and control that would trigger deportation in case of unemployment. Various politicians were suggesting different forms of removing unemployed EU migrants, including deportation if a person had been unemployed for three months (which was the period an EU citizen had to wait before claiming unemployment benefits in the UK at the time), denial of re-entry for a year if someone was deported and deportation without due process for both EU and third country nationals. Daily Mail published a whole article by Theresa May, Home Secretary at the time (Mail on Sunday, 2 March 2014) and regularly cited politicians who favour one or the other of these restrictive measures:

Immigration Minister Mark Harper said the transitional controls were kept for "the longest extent possible". He added: "If you're here from the EU and not working, not studying, not self-sufficient then we can remove you and you won't be able to come back for at least a year” (Daily Mail, 02 January 2014).

Removal of unemployed migrants was also part of the policy problematisation in the German media discussion: “... a great majority of the people agrees that those who come to Germany and do not want to work have to leave the country" (Die Welt, 14 January 2014). The use of the verb "want" in this article implies that poverty is an intentional state chosen by the migrants, reinforcing their criminality. In a similar vein, other media outlets in Germany problematise the consequences for criminal behaviour: "Those who forge documents and wrongfully receive social welfare payments must leave the country permanently" (Frankfurter Rundschau, 6 January 2014). The Frankfurter Rundschau and Die Welt expressed appreciation that the fraudulent behaviour of migrants extracting undue social security payments was to be curtailed and punished, reinforcing the criminal aspect of the migrant worker stereotype they were portraying in the first place:

The government will issue harder punishments in the future in cases of migrants abusing the social welfare system. If migrants fake their data, they will be punished. If they commit fraud, they may not be able to enter the country. Moreover, all EU citizens will only have half a year to find work (Frankfurter Rundschau, 27 August 2014).

Similarly, the UK measures specifying that EU migrant jobseekers could not receive out-of-work benefits, child tax credit or child benefit within the first 
three months after arrival were praised by the Daily Mail: "No longer can people come here from abroad and expect to get something for nothing" (20 January 2014).

\subsection{Frame 2: Policy measures should differentiate among EU migrants}

In the second frame, some media underlined the importance of differentiating among highly skilled and low-/unskilled migrants when designing relevant policies in each country. In Germany, Die Welt spoke in favour of restricting access only for less qualified labour migrants:

Qualified workers are welcome. This is what the German economy needs. But according to the Federal Office of Statistics, $46 \%$ of the Bulgarians and Romanians do not have a vocational training. Why should Germany become the social repair shop of Europe? (6 January 2014).

The Times in the UK also raised concerns about governmental measures not distinguishing between desirable and less desirable workers, thus deterring the desirable ones from deciding to move to the UK:

The upshot of this and similar complex regulations is that desirable immigrants are choosing to go elsewhere, where the rules are less complicated, procedural costs lower and compliance obligations not as demanding (The Times, 17 April 2014).

One set of proposals portrayed in the British media suggested the reinforcement of the tier system already in place for third-country nationals and its introduction for EU migrants. These propositions, put forth in the Daily Mail, favoured the filtering of applicants to those with job offers: "Migrants must have job offers" (Daily Mail, 11 January 2014).

We notice that while the frame of differentiating access to national labour markets and welfare systems among EU migrants based on their marketable skills was present in the German and British media, most of their discussions concentrated on the frame of limiting access for EU migrant workers.

The necessity to reform employment policy rather than immigration or welfare policy was brought in the British media debate by two articles in The Guardian. These articles critically discussed the loopholes in the national Employment Law, which allowed British employers to rely on poorly paid foreign labour. Hence, the authors proposed addressing the root causes of the economic crisis as a fundamental problem and transforming the economic system. However, 
these points were made at the beginning of 2014 and were not followed up during the period covered in the analysis.

\section{$8 \mathrm{EU}$ policy in the national media}

In both countries, the main media portrayal of EU-level policy is that it is distant and disconnected but in direct conflict with member states' labour markets and welfare systems. The media here is, of course, not the only actor in constructing the discourse, but part of the process that reproduces the narrative presented by political actors embedded in the respective labour market and welfare state context. Rather than proposing interventions at the EU level, the media in Germany and the UK discuss how the problem(s) can be solved at the country level, as illustrated in the previous section.

There is one important distinction between the two countries: although the challenges of freedom of movement were highlighted in the debates of both member states, the link to questioning EU membership was made only in the British media. In Germany, the EU is presented as being problematic in the sense that it curtails Germany's ability to regulate their labour market and welfare system, but these reservations do not go as far as to suggest leaving the EU altogether because of that. For example: "The EU constrains the way Germany can regulate the labour market, but the EU common market is also important for the German economy" (Die Welt, January 2014).

The debate in the British media, however, illustrates the tension between national and EU policymaking articulated as a critique of the lack of vision and depth in policy reform, but also as the cause of the problems the UK was facing.

The Labour shadow business secretary, Chuka Umunna, suggested last Thursday that Britain should admit only those from the EU who have guaranteed jobs, rather than men and women seeking work. And what then, after the month's fruit picking was over? Could the migrant be deported? Good luck with that under Britain's EU treaty obligations. In fact, even the notion of admitting EU migrants only if they already had an employment contract would be illegal under EU statute, as Umunna, a lawyer by profession, must have known ([emphasis added] The Times, 12 January 2014).

It is within this frame of understanding the problem of "poverty migration" that Daily Mail and The Times proposed either to reform the relationship that Britain has with the EU, in particular in terms of border control, or to leave the EU altogether, which was presented in terms of a nationwide referendum. 
It's essential we meet that promise and control immigration. ... we really need to judge whether in order to do that will require us to leave the European Union and to control our own borders. Ultimately, I think that's the choice that the country will face in a referendum (Daily Mail, 02 January 2014).

The migration issue was subsequently at the centre of the "Leave" campaign in the referendum held in the UK on 23 June 2016 (see also Gavin 2018).

\section{Analysis and concluding remarks}

This article looks beyond the material practice of labour market exclusions and examines the role of the media in the EU freedom of movement debate. It explores how the media problematised migration from Eastern European countries and its influence on national host country labour markets and welfare systems. It also analysed how different media outlets positioned themselves to relevant policies or policy proposals. The findings show that media portray EU migrants as both contributing to the host country and putting a strain or abusing the national labour markets and welfare systems in the two countries, but also that most articles in our sample present low-skill, low-wage working EU migrant class as a problem.

The media portray freedom of movement in the EU as a problem related to what they label as "poverty migrants" - those that belong to a group of workers characterised by personal or country of origin linked poverty, low-skill, and welfare abusers. Being a "poverty migrant" tends to be considered an individual problem, and not one that is common to the pan-European labour market. Hence, the solution lies at the individual, instead of the national or EU level (see also Borrelli/Bochsler 2020).

Using the tools of critical discourse analysis, we do not consider media as a unitary entity but systematically highlight and discuss the competing frames (Gamson/Modigliani 1989). Four of the analysed media (Daily Mail and The Times in the UK and Die Welt and Frankfurter Rundschau in Germany) consider migration mostly as a problem, whereas The Guardian and Die Zeit do not. However, these media differentiate between the desirable highly skilled and the undesirable low-/unskilled migrants, a distinction that is taken into consideration even when they discuss policy changes in their national contexts. The issue of "poverty migration" is brought to the attention of the public especially by the first four media to support their claims and strengthen their competing representations of reality in relation to EU labour migration and its impact in their society. The underclass of poor Eastern European migrants is presented as a 
threat to the national labour market by undercutting employment opportunities and wages for the local workforce and a threat to the national welfare system by increasing the burden and the abuse on the public purse. These discourses have continued to persist despite the available evidence that EU migrant workers are much less likely to claim benefits in both Germany and the UK (Balch/Balabanova 2016; Bruzelius et al. 2016).

These media discourses, as expressed in four of the German and British newspapers researched, portrayed a protectionist stance against EU freedom of movement. In both contexts, the problem is constructed in terms of unsustainable and undue access of EU migrants to social security institutions and a concern for social cohesion at the community level. However, the right of the freedom to move is not recalibrated for all groups of EU migrant workers. The comparison of Germany and the UK revealed that the general legitimacy of EU freedom of movement was questioned in relation to the "poor" segment of the EU citizenry. Precariously employed EU migrants with limited financial means are the main target for reduced access to social security institutions, a portrayal equated in these media with an underclass of "poverty migrants." These types of migrants are described as financially costly to the state and the taxpayers and a threat particularly to the working class with whom they compete for jobs and resources. In this regard, the media in Germany and the UK follow a trend that has been observed in Denmark, where we are witnessing how people seeking protection from the welfare state are discursively and materially produced as "undeserving" poor (Lindberg 2020).

In Germany, the restriction of EU liberties for this segment could reestablish the legitimacy for EU freedom of movement. By contrast, the UK findings show that freedom of movement is connected to a fundamental critique of EU integration, which could be resolved only by the UK leaving the Union. Therefore, the adopted restrictions did not alter the critique on freedom of movement itself, as in the German case. In fact, German media repeatedly welcomed the inflow of employed labour migrants, preferably qualified employees that could help "advance" the German economy. This does not prevent them from holding a hard line against labour migrants who might find themselves unemployed and use social welfare benefits. There is no differentiation in both countries' media representations between the reasons that EU citizens may find themselves in unemployment (e.g., workers from Eastern European countries may be in an abusive and precarious or informal working situation at a local employer).

Against the background of the national- and EU-level policy discussions, the article also looked at how these policy discussions were reflected on in the 
media. The aim was to show how the backlash against EU migrants is constructed, whom the discussion is targeting and how in and out groups are constructed within the freedom of movement context by certain media outlets. The findings show that the access to social security benefits of EU migrants is accompanied by media portrayals of recipients as less deserving and desirable. Next to the specific processes and mechanisms that put pressure on the welfare state and labour market, this article argues that it is equally important to study the discursive struggles that determine whether intra-EU migration, for example, is understood as acceptable or problematic and how this understanding is constructed. Discussions on "poverty migration" are not only a media catchphrase but construct a different class of workers who are stigmatised for draining the social security system and taking away jobs. Whilst previous research has pointed to the precarious situation these workers find themselves in because of how they are mistreated by their employer, looking at the media discourse portrays a different picture. This is important because our study shows how this image of the "poverty migrant" is mirrored in media discussions in both countries on policies that aim to limit the rights of intra-EU migrants. The focus and connection between the understanding of media and immigration (Boomgaarden/Vliegenthart 2009; Caviedes 2015; Freeman et al. 2013; Schemer 2012), welfare chauvinism (Balch/Balabanova 2016; Bommes/Geddes 2000; Larsen/Dejgaard 2013) and politicisation of European integration (De Wilde 2011; De Wilde/Zürn 2012) can therefore be a powerful way to express the myriad of ways and processes underlying how EU member states exclude and justify the exclusion of EU citizens from social benefits and the national labour market.

Like any research, this study has certain limitations. This article utilised a rather limited project data. As the data were only collected from certain media outlets, the results cannot be generalised. The major strength of this smaller scale study was that the authors provided an example of how the challenging issue of the media discourse in relation to labour migration in the EU can be studied. Further studies are needed in this area to explore the correlation more fully between media discourses on policy reform and the actual policy changes undertaken at the time when the debate on intra-EU migration proliferated. While a media discourse analysis does not allow us to uncover the reasons behind the different attitudes towards the European Union between the UK and Germany, the question is worth exploring, in particular as the UK has been taking official steps to remove itself from the EU, while Germany remains strongly committed to the European project, despite some efforts to manage free movement when it comes to access to its national welfare system. 


\section{Bibliography}

Alberti, Gabriella; Danaj, Sonila (2017): "Posting and agency work in British construction and hospitality: The role of regulation in differentiating the experiences of migrants", International Journal of Human Resource Management 28(21): 3059-3082.

Anderson, Bridget (2013): Us and Them? The Dangerous Politics of Immigration Control. Oxford: Oxford University Press.

Arnholtz, Jens; Hansen, Nana Wesley (2013): “Labour Market Specific Institutions and the Working Conditions of Labour Migrants: The Case of Polish Migrant Labour in the Danish Labour Market", Economic and Industrial Democracy 34(3): 399-420.

Arnholtz, Jens; Lillie, Nathan (eds) (2020): European Integration and the Reconfiguration of National Industrial Relations: Posted Work as a Driver of Institutional Change. London: Routledge.

Balch, Alex; Balabanova, Ekaterina (2016): "Ethics, Politics and Migration: Public Debates on the Free Movement of Romanians and Bulgarians in the UK, 2006-2013", Politics 36(1): 19-35.

Barrett, Alan; McGuinness, Seamus; O’Brien, Martin (2012): “The Immigrant Earnings Disadvantage across the Earnings and Skills Distributions: The Case of Immigrants from the EU's New Member States", British Journal of Industrial Relations 50(3): 457-481.

Baumgartner, Frank R.; Jones, Bryan D. (2002): Policy Dynamics. Chicago: University of Chicago Press.

BBC (2015): Top Court Backs German Block on EU Migrant Benefits. 15 September 2015. Download at: http://www.bbc.com/news/world-europe-34256969 (access on 5 October 2017).

Billig, Michael (1991): Ideology and Opinions. London: Sage.

Black, Richard; Engbersen, Godfried; Okolski, Marek; Panţiru, Cristina (eds) (2010): A Continent Moving West? EU Enlargement and Labour Migration from Central and Eastern Europe. Amsterdam: Amsterdam University Press.

Blaikie, Norman (2000): Designing Social Research. Oxford: Blackwell.

Blauberger, Michael; Schmidt, Susanne K. (2014): "Welfare Migration? Free Movement of EU Citizens and Access to Social Benefits", Research and Politics 1(3): 1-7.

Blumer, Herbert (1954): “What is Wrong with Social Theory?", American Sociological Review 19(1): 3-10.

BMI and BMAS (2014): “Abschlussbericht des Staatssekretärausschusses zu: Rechtsfragen und Herausforderungen bei der Inanspruchnahme der sozialen Sicherungssysteme durch Angehörige der EU-Mitgliedstaaten”. Bonn: Bundesministerium des Innern, Bundesministerium für Arbeit und Soziales.

Bommes, Michael; Geddes, Andrew (2000): Immigration and Welfare: Challenging the Borders of the Welfare State. London: Routledge.

Boomgaarden, Hajo G; Vliegenthart, Rens (2009): “How News Content Influences AntiImmigration Attitudes: Germany, 1993-2005”, European Journal of Political Research 48(4): 516-542.

Borrelli, Lisa Marie; Bochsler, Yann (2020): “Editorial: Governing the Poor - Migration and Poverty”, Zeitschrift für Sozialreform 66(4): 363-385.

Bruzelius, Cecilia; Chase, Elaine; Seeleib-Kaiser, Martin (2016): “Social Rights of EU Migrant Citizens: Britain and Germany”, Social Policy and Society 15(3): 403-416. 
Caviedes, Alexander (2015): “An Emerging ‘European’ News Portrayal of Immigration?”, Journal of Ethnic and Migration Studies 41(6): 897-917.

Cremers, Jan (2011): In Search of Cheap Labour in Europe - Working and Living Conditions of Posted Workers. CLR Studies 6. Brussels: International Books.

De Wilde, Pieter (2011): “No Polity for Old Politics? A Framework for Analyzing the Politicization of European Integration", Journal of European Integration 33(5): 559-575.

De Wilde, Pieter; Zürn, Michael (2012): “Can the Politicization of European Integration Be Reversed?", Journal of Common Market Studies 50(1): 137-153.

Ehata, Rebecca; Seeleib-Kaiser, Martin (2017): "Benefit Tourism and EU Migrant Citizens: RealWorld Experiences”, Social Policy Review 29: 181-197.

Esmark, Anders; Schoop, Sarah R. (2017): “Deserving Social Benefits? Political Framing and Media Framing of 'Deservingness' in Two Welfare Reforms in Denmark”, Journal of European Social Policy. First published: 17 February 2017. DOI: 10.1177/0958928716688262.

Esping-Andersen, Gøsta (1990): The Three Worlds of Welfare Capitalism. Princeton: Princeton University Press.

Eurostat (2016): EU Labour Force Survey 2016, available at: https://ec.europa.eu/eurostat/documents/1978984/6037342/EU-LFS-explanatorynotes-from-2016-onwards.pdf (access on 24 April 2021).

Fairclough, Norman (1992): Language and Power. London: Longman.

Foster, Steven (2010): Media Power and Media Effects: Theories and Realities in Political Communication. Edinburgh: Edinburgh University Press.

Franklin, Bob (2002): Social Policy, the Media and Misrepresentation. London: Routledge.

Freeman, Gary P.; Hansen, Randall; Leal, David L. (eds) (2013): Immigration and Public Opinion in Liberal Democracies. London: Routledge.

Galgóczi, Béla; Leschke, Janine; Watt, M. Andrew (eds) (2013): EU Labour Migration Since Enlargement: Trends, Impacts and Policies. Surrey: Ashgate.

Gamson, William A. (1992): Talking Politics. Cambridge: Cambridge University Press.

Gamson, William; Modigliani, Andre (1989): “Media discourse and public opinion on nuclear power: A constructionist approach”, American Journal of Sociology 95(1): 1-37.

Gavin, Neil T. (2018): “Media Definitely Do matter: Brexit, Immigration, Climate Change and Beyond", The British Journal of Politics and International Relations 20(4): 827-845.

Geddes, Andrew; Hadj-Abdou, Leila (2016): “An Unstable Equilibrium: Freedom of Movement and the Welfare State in the European Union”, in: Gary Freeman; Nikola Mirilovic (eds): Handbook on Migration and Social Policy. Cheltenham: Edward Elgar, 222-238.

Golding, Peter (2002): “Thinking the unthinkable: welfare reform and the media”, in: Bob Franklin (ed.): Social Policy, the Media and Misrepresentation. London: Routledge, 146156.

Heindlmaier, Anita; Blauberger, Michael (2017): "Enter at your own risk: free movement of EU citizens in practice", West European Politics 40(6): 1198-1217.

House of Commons (2015): Measures to limit migrants' access to benefits. 17 June 2015. Download at: http://researchbriefings.parliament.uk/ResearchBriefing/Summary/SN06889 (access on 24 April 2021).

Jurado, Elena; Brochmann, Grete (eds) (2013): Europe's Immigration Challenge: Reconciling Work, Welfare and Mobility. London: I.B. Tauris.

Lafleur, Jean-Michel; Stanek, Mikolaj (2017): “Restrictions on Access to Social Protection by New Southern European Migrants in Belgium”, in: Jean-Michel Lafleur; Mikolaj Stanek 
(eds): South-North Migration of EU Citizens in Times of Crisis. Dordrecht: Springer, 99121.

Larsen, Christian Albrekt; Dejgaard, Thomas Engel (2013): “The Institutional Logic of Images of the Poor and Welfare recipients: A Comparative Study of British, Swedish and Danish newspapers", Journal of European Social Policy 23(3): 287-299.

Lillie, Nathan (2010): "Bringing the Offshore Ashore: Transnational Production, Industrial Relations and the Reconfiguration of Sovereignty", International Studies Quarterly 54(3): 683-704.

Lindberg, Annika (2020): “The Production of Precarity in Denmark’s Asylum Regime”, Zeitschrift für Sozialreform 66(4): 419-439.

Luthra, Renee; Platt, Lucinda; Salamońska, Justyna (2016): “Types of Migration: The Motivations, Composition, and Early Integration Patterns of 'New Migrants' in Europe”, International Migration Review. First published: 03 October 2016. DOI:

https://doi.org/10.1111/imre.12293

Massey, Douglas; Denton, Nancy (1993): American Apartheid: Segregation and the Making of the Underclass. Cambridge: Harvard University Press.

Mautner, Gerlinde (2008): “Analyzing Interaction in Broadcast Debates”, in: Ruth Wodak; Michat Krzyżanowski (eds): Qualitative Discourse Analysis in the Social Sciences. London: Palgrave Macmillan.

Mawby, Rob C.; Gisby, William (2009): "Crime, Media and Moral Panic in an Expanding European Union", The Howard Journal of Crime and Justice 48(1): 37-51.

McCombs, Maxwell E. (2004): Setting the Agenda: The Mass Media and Public Opinion. Malden: Blackwell.

Patterson, Thomas E. (2008): “Political Roles of the Journalist”, in: Doris A. Graber; Denis McQuail; Pippa Norris (eds): The Politics of News, The News of Politics. Washington: CQ Press, 17-32.

Pew Research Center (2018): Fact Sheet: News Media and Political Attitudes in the United Kingdom. Download at: https://www.pewresearch.org/global/fact-sheet/news-mediaand-political-attitudes-in-the-united-kingdom/ (access on 24 April 2021).

Roos, Christof (2016): "Freedom of Movement in the EU and Welfare State Closure: Welfare Regime Type, Benefit Restrictions and Their Implications for Social Mobility”, in: Melike Wulfgramm; Tonia Bieber; Stephan Leibfried (eds): Welfare State Transformations in the 21st Century: Effects on Social, Economic and Political Inequality in OECD Countries. Basingstoke: Palgrave Macmillan, 267-289.

Schemer, Christian (2012): "The influence of news media on stereotypic attitudes toward immigrants in a political campaign”, Journal of Communication 62(5): 739-757.

Schlueter, Elmar; Davidov, Eldad (2011): “Contextual Sources of Perceived Group Threat: Negative Immigration-Related News Reports, Immigrant Group Size and Their Interaction, Spain 1996-2007", European Sociological Review 29(2): 179-191.

Shutes, Isabel (2016): "Work-Related Conditionality and the Access to Social Benefits of National Citizens, EU and Non-EU citizens”, Journal of Social Policy 45(4): 691-707.

Smith, Mathew (2017): “How Left- or Right-Wing Are Britain's Newspapers?”, The Times 6 March 2017. Download at: https://www.thetimes.co.uk/edition/news/how-left-or-rightwing-are-britain-s-newspapers-8vmlr27tm (access on 24 April 2021).

University of Chicago Online Resources (n.d.): The Media in the German Speaking Countries. Download at: https://german.uchicago.edu/links/media (access on 5 October 2017). 
Wagner, Ines (2018): Workers without borders: posted work and precarity in the EU. Ithaca: ILR Press.

Wodak, Ruth; Meyer, Michael (eds) (2009): Methods for Critical Discourse Analysis. London: Sage.

Wolfe, Michele; Jones, Bryan D.; Baumgartner, Frank R. (2013): “A Failure to Communicate:

Agenda Setting in Media and Policy Studies”, Political Communication,30(2): 175-192.

\section{Acknowledgments}

This research was supported by the European Research Consortium [grant number TWES 263782]. The authors would like to thank the two anonymous reviewers for their comments and the editors of the special issue "Governing the Poor - Migration and Poverty" for the very constructive guidance throughout the whole process.

\section{Short Biographies}

Sonila Danaj is a doctoral candidate in Sociology at University of Jyväskylä, Finland and she works as a researcher at the European Centre for Social Welfare Policy and Research in Vienna, Austria. Her research interests include labour mobility and migration, atypical employment, working conditions, trade unions and migrant workers, and social dialogue.

Dr. Ines Wagner is a Senior Researcher at the Institute for Social Research in Oslo. Her research interests include the politics labour mobility in the European labour and product market, gender and work as well as the future of work and technological change. 